\title{
SLC23 family of ascorbic acid transporters (version 2019.4) in the IUPHAR/BPS Guide to Pharmacology Database
}

James M. May ${ }^{1}$

1. Vanderbilt University, USA

\begin{abstract}
Predicted to be 12 TM segment proteins, members of this family transport the reduced form of ascorbic acid (while the oxidized form may be handled by members of the SLC2 family (GLUT1/SLC2A1, GLUT3/SLC2A3 and GLUT4/SLC2A4). phloretin is considered a non-selective inhibitor of these transporters, with an affinity in the micromolar range.
\end{abstract}

\section{Contents}

This is a citation summary for SLC23 family of ascorbic acid transporters in the Guide to Pharmacology database (GtoPdb). It exists purely as an adjunct to the database to facilitate the recognition of citations to and from the database by citation analyzers. Readers will almost certainly want to visit the relevant sections of the database which are given here under database links.

GtoPdb is an expert-driven guide to pharmacological targets and the substances that act on them. GtoPdb is a reference work which is most usefully represented as an on-line database. As in any publication this work should be appropriately cited, and the papers it cites should also be recognized. This document provides a citation for the relevant parts of the database, and also provides a reference list for the research cited by those parts.

Please note that the database version for the citations given in GtoPdb are to the most recent preceding version in which the family or its subfamilies and targets were substantially changed. The links below are to the current version. If you need to consult the cited version, rather than the most recent version, please contact the GtoPdb curators.

\section{Database links}

SLC23 family of ascorbic acid transporters

http://www.guidetopharmacology.org/GRAC/FamilyDisplayForward?familyld=201

Transporters

SVCT1(Sodium-dependent vitamin C transporter 1)

http://www.guidetopharmacology.org/GRAC/ObjectDisplayForward?objectld=1041

SVCT2(Sodium-dependent vitamin C transporter 2)

http://www.guidetopharmacology.org/GRAC/ObjectDisplayForward?objectld=1042

SVCT3(Sodium-dependent vitamin C transporter 3)

http://www.guidetopharmacology.org/GRAC/ObjectDisplayForward?objectld=1043 
SNBT1(Sodium-dependent nucleobase transporter)

http://www.guidetopharmacology.org/GRAC/ObjectDisplayForward?objectld=1044

\section{References}

1. MacDonald L, Thumser AE and Sharp P. (2002) Decreased expression of the vitamin C transporter SVCT1 by ascorbic acid in a human intestinal epithelial cell line. Br. J. Nutr. 87: 97-100 [PMID:11895172]

2. Tsukaguchi H, Tokui T, Mackenzie B, Berger UV, Chen XZ, Wang Y, Brubaker RF and Hediger MA. (1999) A family of mammalian Na+-dependent L-ascorbic acid transporters. Nature 399: 70-5 [PMID:10331392]

3. Yamamoto S, Inoue K, Murata T, Kamigaso S, Yasujima T, Maeda JY, Yoshida Y, Ohta KY and Yuasa H. (2010) Identification and functional characterization of the first nucleobase transporter in mammals: implication in the species difference in the intestinal absorption mechanism of nucleobases and their analogs between higher primates and other mammals. J. Biol. Chem. 285: 6522-31 [PMID:20042597] 